\title{
The Meeting of the Comission on Faith and Order at the Monastery of Caraiman, Busteni, Romania, 17-24 June 2015
}

\author{
DANIEL BUdA*
}

The first task of the Commission on Faith and Order meeting in Caraiman Monastery was to bring its members together in order to know each other and to discern what specific work will be done over the next seven or eight years, and to determine the specifics of how this work shall be carried out.

The meeting of the Commission was opened by Moderator`s address, followed by formal greetings from His Beatitude Daniel, Patriarch of the Romanian Orthodox Church presented by His Eminence Nifon of Targoviste. Archimandrite David Petrovici, the Abbot of the Monastery of Caraiman welcomed the Commission to his monastery, noting this marks an historic moment in the life of his monastic community. After introductions of the Commission members, the Moderator of the Commision, Dr. Susan Durber introduced the newly appointed Director of the Faith and Order Secretariat, Rev. Prof. Dr Odair Pedroso Mateus.

WCC General Secretary, Rev. Dr Olav Fykse Tveit addressed the Commission, talking about the new beginnings in its history: new membership, newly appointed director and staff and new study themes which the Commissioners will be called to discern and select. He noted that prior to the commission meeting he met with the President of Romania, His Excellency Klaus Werner Johannis who expressed genuine interest in the work of the WCC in general and of Faith and Order in particular and in how the state and the Romanian churches and religious communities can work collaboratively for the common good of Romanian and European societies. He also met with His Beatitude Patriarch Daniel, who shared again his vision for the Romanian Orthodox Church and for church unity. WCC General Secretary invited the Commission to understand itself as a "fellowship of resources" human, spiritual, theological - for the purpose of bringing all of us forward into deeper understanding and commitment to find new expressions of the

* Daniel Buda, Rev. PhD Associated Professor at the "Andrei Şaguna" Faculty of Orthodox Theology, "Lucian Blaga" University of Sibiu, Romania; Programme Executive Coordinator for Church and Ecumenical Relations at WCC, Geneva. Contact details: WCC, Route de Ferney 150, 1211 Geneva 2, Switzerland; e-mail: daniel 77bde@yahoo.de.

1 This presentation follows the Minutes of the Commission on Faith and Order meeting at the Monastery of Caraiman, Busteni, Romania, 17-24 June 2015, Faith and Order Paper no. 222, Geneva, 2015.

RES 8 (1/2016), p. 134-139

DOI: $10.1515 /$ ress-2016-0009 
call to unity. He challenged the Commission to see itself within the framework of the WCC's Pilgrimage of Justice and Peace, which he described as "a journey of faith" which itself is driven by faith - a movement forward toward new tasks and an openness to new experiences and doing things differently.

In the afternoon of Thursday 18 June, the Commissioners met in small groups for the purpose of discussing contextual ecclesiological issues. The purpose of the small groups was to enable the Commissioners to share the concerns emerging from their respective contexts. This sharing was the first step in helping Faith and Order to discern issues with which it will engage during this mandate. The day ended with a session on "Consensus-based decision making."

The day of Friday 19 June started with two reporting sessions of the Secretariat of Faith and Order entitled "From Yesterday to Tomorrow." The reports have been presented by the staff and some members of the Commission who were particularly involved in the Commission work. Reports were presented on: (1) study on ecclesiology, (2) sources of authority (3) Baptism (4) Study on moral discernment.

The study on ecclesiology was presented based on a background paper "Six Brief Historical Notes on the Faith and Order Study on Ecclesiology." Fr. Henn offered a presentation to the Commission on the more than 20-years development of The Church: Toward a Common Vision. The report on Sources of Authority was presented by Daniel Buda. ${ }^{2}$ The report on Baptism was presented by Dr. Dagmar Heller. She noted that even after the broad consensus reached in the famous document Baptism, Eucharist and Ministry there are still questions related with Baptism which need more dialogue and discernment among churches. She mentioned a consultation which took place in Kingston, Jamaica in January 2015 on the initiative of churches that practice believer's baptism. IT was for the first time when churches of this tradition met together to reflect on mutual recognition of baptism. Such a work needs to continue in the future.

The Study on moral discernment was presented also by Dr. Heller who provided a brief historical overview of Faith and Order's work on moral discernment in the churches. Dr. Peters offered a presentation on the 2013 Faith and Order study document Moral Discernment in the Churches. It is important to understand that the text produced by this working group is a study text $\mathrm{i}$. e. is a text which does not have the authority of a Faith and Order document. She expressed the hope that Faith and Order Commission will approve to continue the work in the area of moral discernment.

\footnotetext{
2 See the entire report as appendix to this presentation.
} 
In the afternoon of Friday 19 June, Rev. Dr. Hielke Wolters, WCC Associate General Secretary, presented a paper entitled "Faith and Order and the World Council of Churches." He emphasized the important role which the commission on Faith and Order is called to play within WCC and in the ecumenical movement. The Pilgrimage of Justice and Peace, to whom the Busan Assembly called all Christians to join, have both a missiological and ecclesiological perspective. More reflection is needed on the theological, ecclesiological, missiological, diaconal, and ethical understanding of the key concepts of pilgrimage, justice and peace - which have the potential to be church-dividing concepts.

In the same afternoon, Metropolitan Geevarghese Mor Coorilos, Moderator of the Commission on World Mission and Evangelism (CWME) presented an addressed on behalf of CWME that he named a "sister commission." He presented briefly the activity of CWME and called for a stronger collaboration with Faith and Order. As an example of concrete collaboration in the past, he mentioned the fact that Faith and Order invited CWME to provide a response on an earlier draft of the ecclesiology text The Nature and Mission of the Church. Similarly, CWME invited Faith and Order to comment on the document Together Towards Life, especially on the section Spirit of Community: Church on the Move" which reflects ecclesiology on mission.

One of the Commission's tasks was to select up to five vice-moderators who will assist in the moderating of working sessions and share in the overall leadership of Faith and Order. In this sense, a Nomination Committee was formed and Commissioners were invited to suggest names. The morning (closed) session of Saturday 20 June dialed with the election of the vice-moderators for the Commission. The elected vice-moderators are: Metropolitan Gennadios of Sassima (Ecumenical Patriarchate, Turkey), Prof. William Henn (Roman Catholic Church), Rev. Morag Logan (Uniting Church of Australia), Rev. Makhosazana Nzimande (Anglican \$Church of Southern Africa) and Rev. Hermen Shastri (Methodist Church in Malaysia).

In three consecutive sessions that took place on Saturday 20 June, the commissioners reflected on discerning the work of coming years. The following three study groups have been formed: The Church on a Pilgrimage of Justice and Peace in Today`s World; Pilgrimage Towards a Common Vision of the Church and The Church on a Pilgrimage of Justice and Peace Engaged in Moral Discernment. After further reflections which took place also on Monday 22 June, the study groups' tasks may be summarized as following:

1. The Church on a Pilgrimage of Justice and Peace in Today`s World is aimed to address the burning issues facing human beings today: jus- 
tice, peace, protection of creation and the need to protect them; racism, migration, exploitation of the planet ; the voice of the church in the public square etc. This study group has three subgroups: (1) Theological and Ecclesiological Foundations of Pilgrimage, Justice and Peace - aimed to mark a significant contribution to the overall WCC theme of "Pilgrimage of Justice and Peace"; (2) Living the Gospel of Jesus Christ in a Pluralistic World - aimed to explore the churches' ways of living as Christians in multi-religious and multi-cultural situations; and (3) Christian Responsibility and Hope for a Broken World - aimed to research further themes related to justice and peace such as migration, creation and environmental crisis from a theological and ecclesiological perspective. The co-moderators of this working group are: Sandra Beardshall (United Church of Canada) and Jaeshik Shin (Presbyterian Church of Korea).

2. Pilgrimage Towards a Common Vision of the Church is aimed to go into wider contact with churches who have not yet been part of discussions on the way to the ecclesiological document called The Church Towards a Common Vision (TCTCV). This study group has also two sub-groups: (1) New \& emerging ways of being church, and (2) Ecclesiology from BEM to TCTCV. The co-moderators of this working group are: Angela Berlis (Old Catholic Churches of the Union of Utrecht) and Jack Khalil (Greek Orthodox Patriarchate of Antioch and All the East).

3. The Church on a Pilgrimage of Justice and Peace Engaged in Moral Discernment. This study group will focus on facilitating the reception of the study document Moral Discernment in the Churches and on deepening the knowledge about moral discernment processes in the churches and identifying uniting and dividing factors related with this issue. The co-moderators of this working group are: Vladimir Shmaliy (Russian Orthodox Church) and Myrian Wijlens (Roman Catholic Church).

On Sunday 21 June, the commissioners attended the Divine Liturgy at the church of the monastery at Caraiman and in the afternoon visited the Castle of Peles.

On Monday 22 June the Commission received the visit of His Beatitude Daniel, Patriarch of the Romanian Orthodox Church. His Beatitude was greeted by the Moderator of the Commission who acknowledged his personal experience with the work of Faith and Order. She thanked him for the hospitality of his church in hosting this meeting of the Commission in a 
facility of the Romanian Orthodox Church. His beatitude greeted the entire membership of the Commission and presented the work of renewal that is going on presently in the Romanian Orthodox Church. The focus is on education. His Church is involved in trying to reduce the high dropout rate in Romania. Talking about church unity, His Beatitude noted the tendency of some churches from the spirit of seeking unity to one more focused on their own specific identity. A festive lunch followed the meeting with His Beatitude Patriarch Daniel.

The next meeting of the commission on Faith and Order will take place in 2017.

The Commission on Faith and Order has presently 49 members which were elected by the central Committee of WCC gathered in Geneva in June 2014. According to the Constitution of Faith and Order Commission its primary purpose is „serve the churches as they call one another to visible unity in one faith and in one Eucharistic fellowship, expressed in worship and common life in Christ, through witness and service to the world, and advance towards that unity in order that the world may believe."3

\section{Appendix: Information on the study on Sources of Authority ${ }^{4}$}

The Faith and Order Plenary Commission gathered in Kuala Lumpur, Malaysia, 2004 proposed to study various sources that are believed to be authoritative in churches and therefore foundational for the distinctive interpretations. The proposal came from HE Metropolitan Hilarion Alfeyev and after further discussions and adjustments was included in the wider study on Ecumenical Hermeneutics. It was agreed to begin with the authority of the early church teachers and witnesses, namely with the Fathers of the Church.

A first consultation with the title "The Teachers and Witnesses of the Early Church: A Common Source of Authority, Variously Received?" has been held from the $1^{\text {st }}$ to $6^{\text {th }}$ of September 2008 at Westminster College, Cambridge, UK. The main reason for starting this study on Sources of Authority with the early church was the common ground that all Christianity finds in it. While the Church Fathers are the foundation of the Orthodox tradition and play an important role in other traditions, further reflection on how much other traditions value them helped to rediscover together common

3 Faith and Order`s by-laws, as approved by WCC Central Committee in 2014.

4 The text is reproduced in Minutes of the Commission on Faith and Order ... Paper 222, p. 74-75. 
roots and reduce the gap of misunderstanding. Five major contributions on Sources of Authority in the Early Church were presented from the following perspectives: Eastern Orthodox, Oriental Orthodox, Roman Catholic, Anglican and Methodist. Two theologians, one from the same or similar tradition and the other from different tradition, responded to each of these papers.

A second consultation gathered in Moscow from 29 June to 2 July 2011 and reflected on how different churches and traditions perceive authority today and on possible common thought with regard to authority. Nine major contributions reflected on a variety of sources of authority from different perspectives: (1) Experience as a Source of Authority for Faith; (2) Indigenous Peoples' Perspective on the Sources of Authority; (3) The Holy Spirit as a source of Authority in the African Independent Churches; (4) Congregation as a Source of Authority in Baptist Ecclesiology; (5) Sources of Authority in Lutheran Churches at Present; (6) Reason as a source of Authority in the Anglican Tradition; (7) Liturgical Texts as a Source of Authority in the Coptic Orthodox Church; (8) Hierarchy as a Source of Authority in the (Eastern) Orthodox Church; (9) The Magisterium in the Catholic Church as a Source of Authority. Each major contribution received a response from a theologian representing the same or a different tradition.

A final report reflects on where we are now with regard to our perceptions on authority in the Church and its sources. While several common points are identified, the final part of the report states that: "Many questions were raised around the issue of the sources of authority that are still pending in churches today. There are two main ways to work ecumenically in this direction; first, to identify the sources of authority, which the consultation has already begun to do, and second, to discern what God is saying to the faithful through these sources. The Faith and Order Commission must continue the search for the ecumenical discernment of authority in the church for the sake of unity." 